\title{
Das
}

THE WILLIAM DAVIDSON INSTITUTE AT THE UNIVERSITY OF MICHIGAN BUSINESS SCHOOL

\section{Differential Rewards to, and Contributions of, Education in Urban China's Segmented Labor Markets}

By: Margaret Maurer-Fazio and Ngan Dinh

William Davidson Working Paper Number 508

June 2002 


\title{
Differential Rewards to, and Contributions of, Education in Urban China's Segmented Labor Markets
}

\author{
Margaret Maurer-Fazio* \\ Department of Economics \\ Bates College \\ Lewiston, ME 04240 \\ (207) 786-6097 (phone) \\ (207) 786-8337 (fax) \\ mmaurer@bates.edu \\ http://www.bates.edu/ mmaurer \\ and \\ Ngan Dinh \\ Apt. 774 International House \\ 1414 East 59th Street \\ Chicago, IL 60637 \\ ndinh@midway.uchicago.edu
}

June 2, 2002

Journal of Economic Literature Classification Codes:

J20, J22, J31, J64, J71, O15, O53, P23, P36

Keywords:

wages, China, unemployment, discrimination, transitional economies, employment determination, labor

* Contact Author 


\begin{abstract}
:
Education's role in determining worker incomes in China's rapidly changing urban labor markets is investigated in this paper. Using worker data from a 1999-2000 urban enterprise survey, we examine the effects of education on the current earnings of continuously-employed urban workers, migrants, and laid off but subsequently reemployed workers, as well as on the most recent earnings of laid-off (but not subsequently re-employed) workers. We also decompose the earnings differentials between each of these groups of workers and then assess the contribution of education to explanations of the differentials.

The empirical results demonstrate that educational attainment remains an important explanator of earnings differentials between institutionally-differentiated groups of workers in China's urban labor markets. An interesting hierarchy of returns to education has developed. The education of migrants is generally poorly rewarded. The moderate returns to educational investments of the continuously-employed urban residents rank next. Re-employed urban residents experience the highest rewards to their education, especially those who used a competitive means to find their post-layoff employment. When we assess the earning differentials between groups using the continuouslyemployed urban residents as the basis of comparison, differences in educational attainments alone contribute between 16 and 52 percent of the explanation of the total inter-group wage gaps.
\end{abstract}




\section{Differential Rewards to, and Contributions of, Education in Urban China's Segmented Labor Markets}

\section{Introduction:}

This paper studies the role of education in determining worker incomes in China's rapidly changing urban labor markets. Using worker data from a 1999-2000 urban enterprise survey, we examine the effects of education on the current earnings of continuously-employed urban workers, migrants, and laid off but subsequently reemployed workers, as well as on the most recent earnings of laid-off (but not subsequently re-employed) workers. We also decompose the earnings differentials between each of these groups of workers and then assess the contribution of education to explanations of the differentials.

The empirical results demonstrate, not surprisingly, that the human capital of urban residents is better rewarded than that of migrant workers. Furthermore, the human capital accumulation of workers who have suffered a layoff but managed to find new employment is rewarded more, in terms of incremental earnings for each additional year of schooling, than that of continuously-employed urban workers. Interestingly, reemployed workers' education is better rewarded in these workers' post-layoff jobs than it was in their pre-layoff jobs.

When we assess the earning differentials between groups using the continuouslyemployed urban residents as the basis of comparison we can explain, in terms of differences in productive characteristics, 75 percent of the earnings gap for migrants, 40 percent of the gap for laid-off workers, and -8 percent of the earnings gap for reemployed workers. Differences in educational attainments alone contribute between 16 and 52 percent of the explanation of the total wage gaps between groups. 


\section{Background:}

Changes to China's agricultural production system in the late 1970s and early 1980s created irresistible pressure for change in labor mobility. The subsequent loosening of migration restrictions in the mid-1980s allowed large numbers of rural residents to look for work in urban areas. Rural-to-urban migration snowballed_-by 199645 million migrants were seeking work in cities (Rural Development Institute, 1998).

As Roberts describes:

The migrants have transformed the cities of China. They build skyscrapers, sell vegetables, clothes, and a variety of other commodities in markets that previously did not exist, prepare and serve food sold in sidewalk stands and fine restaurants, fix bicycles and plumbing, and do the hard and dirty work in factories, transport, and sanitation. (2001, p.16)

The state's household registration (hukou) system classifies individuals according to residence and economic status. Each person's hukou records their place of presumed regular residence (suozaidi), that is, the place they belong to, as well as their status (leibie) — agricultural or non-agricultural. The latter classification is more typically referred to as rural or urban and itself determines an individual's eligibility for state provided services, benefits, and jobs. (Chan and Zhang 1999, Fan 1999). Migrants working in urban areas are typically both away from their registered place of residence and classified as agricultural workers.

The agricultural/non-agricultural classification was originally based on occupation but currently bears little relationship to occupation: tens of millions of individuals working in off-farm jobs are classified as agricultural. The hukou system divides Chinese society into two groups — privileged state-supported urban (nonagricultural) elites and underprivileged self-reliant rural (agricultural) residents. (Chan and Zhang 1999, Fan 1999). Hukou registration is not a matter of choice-accidents of 
birth rather than personal preferences determine one's hukou status and hukou status greatly influences one's economic opportunities.

Recent empirical work investigating the extent of labor market segmentation and discrimination in China's urban labor markets has focused, appropriately, on the rural/urban dichotomy. In a Shanghai-based sample of urban residents and migrants, Meng and Zhang (2001) find that 22 percent of urban residents are in occupations above that warranted by their productive characteristics while 6 percent of migrants are in jobs below that warranted by their qualifications. They also find, once the occupational distribution is taken into account, that the entire pay gap between these two groups is left unexplained--presumably due to unfair treatment. Meng's (2002) exploration of the source of discrimination against migrant workers employed in urban industrial enterprises suggests that urban residents are the "insiders" in profit-sharing firms while migrants are "outsiders" with no claims to enterprise profits. Knight, Song, and Jia, (1999) employing a similar enterprise-based survey of employed migrants, report the marginal product of migrants exceeds their wages by a factor of more than three while, in contrast, the wages of urban residents exceed their marginal product. They also report that managers view migrants as desirable, hard-working, and flexible employees and would hire more of them if not constrained from doing so by government policies. Fan finds resident status a central factor in explaining labor market segmentation (2002) and reports that resident status functions like an ascribed attribute, rather than achieved attributes, in determining labor market outcomes (2001).

The state's concerns about open unemployment and social instability in urban areas initially caused the Chinese leadership to take a slow, cautious approach in its 
transition to a market economy. Consequently, the demands for more flexible and efficient labor markets brought by a new generation of profit-motivated managers were at first resisted, experimented with, and introduced only gradually. By the mid-1990s, however, concerns about state-sector inefficiency began to override concerns about dismissals and layoffs. This led to the policy of putting workers on xiagang, a form of layoff in which workers were placed on inactive status and sent home with small stipends. The policy was applied nation-wide in 1997. Massive layoffs of urban workers resulted: by the end of the year, between 11 and 15 million were put on xiagang. ${ }^{1}$ Over 25 million workers were laid-off (put on xiagang) in the first three years of the policy. 9.4 million workers remained in the ranks of the laid-off as of year's end 1999 (Zhongguo laodong tongji nianjian,2000).

Enterprise restructuring has forced urban workers to bear much of the cost of a painful adjustment process as enterprises shed redundant workers. Workers are no longer shielded from market forces. Laid-off workers experience substantial periods of unemployment with minimal stipends (Appleton et. al., 2002). Income inequality is widening. In the early reform period, increases in income inequality meant that those at the low end of the income distribution lost out relative to those at the high end of the distribution despite experiencing rising incomes. In the current period of extensive layoffs those at the low end of the distribution are experiencing substantial reductions in their income (Meng 2001).

\footnotetext{
${ }^{1} \mathrm{Li}$ (1997) reports State Statistical Bureau estimates of 15 million redundant employees. Li (1998) also quotes the former Minister of Labor, Li Boyong, as reporting 11.51 million lay-offs in 1997, of which 7.87 million were from state-owned enterprises.
} 
The plight of these displaced urban workers is compounded by competition from rural migrants seeking work. Although migrants are reported to do the work that urban residents disdain — the jobs that are dangerous, demanding, and dirty, the stage is clearly set for a conflict of interest between migrants and urban residents. As will be shown below, a number of urban enterprises both lay off urban workers and employ migrants in production line positions.

The implementation of xiagang policies has changed the landscape of urban labor markets. Labor market participants can no longer just be analyzed simply according to hukou status as either protected, elite urban residents or migrants. Laid-off urban residents are now a prominent feature of the urban terrain and must be taken into consideration in labor market analyses. Education is a key determinant of both the lay-off and re-employment processes (Maurer-Fazio, forthcoming). In many urban enterprises particular urban residents are selected for layoff while others keep their jobs. The consequences being laid-off vary: some of the laid-off workers find new employment quickly while others suffer extended spells of unemployment.

In one sense this paper can be viewed as simply reporting both the returns to education and the contribution of education to explaining wage differentials for a rich array of market participants: continuously-employed urban residents, migrant workers, laid-off workers, and laid off but re-employed workers. In another sense, by examining differences in the returns to education between these groups this paper explores the degree of integration, or lack thereof, in China's urban labor markets in1999 and 2000, a period in which workers faced both a great deal of uncertainty and a rapidly changing work environment, a period in which the potential for greater competition and conflict 
between laid-off workers and migrants has arisen. We seek answers to a series of related questions: How do the productive characteristics of migrants compare to those of the redundant workers and of employed urban residents? How are redundant workers faring in the transition? How does the labor market treatment of migrants compare to that of urban residents whether continuously employed or laid off?

\section{The Data}

The data were gathered in the fall of 1999 and spring of 2000 as part of the Urban Labor Market Integration Project. ${ }^{2}$ The data set is enterprise based and ties together enterprise information with that of workers of three different categories: employed urban residents, laid-off urban residents, and employed migrants. Surveys were conducted at 118 enterprises, roughly 20 in each of six cities: Beijing, Nanjing, Wuhan, Xian, Tianjin, and Changchun.

Industry type (hangye) was the primary selection criteria for inclusion of an enterprise in the survey process. In each city several textile, mechanical processing, and construction firms were selected. The remaining enterprises were chosen according to the industrial mix of each city. Secondary selection criteria dictated that, within an industry, enterprises be selected to provide firms differing in scale, economic prosperity, and ownership. Firms known to have laid-off workers or to have both laid-off workers and hired migrants were deliberately over sampled. At the time of the survey, 83 of the sample's 118 enterprises had a number of laid off workers on their rolls. Approximately

\footnotetext{
2 The Urban Labor Market Integration Project was funded by the Ford Foundation, Beijing Office and was carried out by principle investigators: Fang Cai (Population Institute, Chinese Academy of Social Sciences), Margaret Maurer-Fazio (Department of Economics, Bates College), Xin Meng (Research School of Pacific and Asian Studies, Australia National University), and Hansheng Wang (Department of Sociology, Peking University).
} 
half the firms had both migrant and laid-off workers. About one third of the firms had laid-off workers but no migrant employees. A smaller number of the enterprises (approximately 15 percent) had hired migrants and had never laid-off members of their urban-resident work force. The remainder of the firms hired only urban residents and had no laid-off workers on their rolls.

Approximately 800 individuals in each of the six cities mentioned above, each associated with one of the selected enterprises, were surveyed — 4873 individuals in total. Once an enterprise was chosen for inclusion in the sample then roughly 15 workers of each type (employed urban resident, laid-off urban resident, and migrant) were selected. The employed urban residents were randomly chosen from those present at the job site at the time of the survey. The laid-off workers were called back to the enterprise to participate in the survey. This callback method introduces a potential source of bias into the sample-laid-off workers subsequently employed in other locations are most unlikely to have responded to the enterprise callback. Migrant workers were surveyed either at the job site or in their employer-provided dormitories. In all cases, survey overseers were present in the room while respondents completed the surveys. They were thus available to observe the process and answer questions. The worker surveys included questions regarding background information, work history, income, expenditures, and attitudes.

It is important to note that the workers designated here as "laid-off" (i.e., labeled as xiagang gong ren) are so designated because the enterprises that anchor the surveys identified them as such. Almost one third of these "laid-off" workers reported finding jobs subsequent to their lay-offs although only one quarter remained employed at the time of the survey. 


\begin{tabular}{|c|c|c|c|c|c|c|c|c|c|}
\hline & \multicolumn{3}{|l|}{ Migrant } & \multicolumn{3}{|l|}{ Laid-off } & \multicolumn{3}{|l|}{ Urban } \\
\hline & & Male & Female & & Male & Female & & Male & Female \\
\hline Number of Observations & 1450 & $71.8 \%$ & $28.1 \%$ & 1564 & $43.46 \%$ & 56.54 & 1859 & $51.7 \%$ & $48.3 \%$ \\
\hline Average age & 28.46 & 29.61 & 25.57 & 39.20 & 39.95 & 38.62 & 38.24 & 39.32 & 36.98 \\
\hline$\%$ Married & 51.2 & 56.7 & 37.2 & 83.51 & 78.78 & 87.12 & 83.8 & 82 & 85.8 \\
\hline$\%$ Party members & 4.9 & 5.9 & 2.2 & 2.26 & 3.86 & 1.03 & 12.2 & 13.1 & 5.7 \\
\hline \multicolumn{10}{|l|}{ Education Background } \\
\hline Years of schooling & 9.04 & 8.98 & 9.18 & 10.57 & 10.42 & 10.68 & 11.69 & 11.58 & 11.82 \\
\hline$\%$ No formal education & 1.2 & 1.4 & 0.7 & 0.19 & 0.30 & 0.11 & 0.1 & 0.1 & 0 \\
\hline$\%$ Junior primary & 1.1 & 1.3 & 0.7 & 0.32 & 0.45 & 0.23 & 0 & 0 & 0 \\
\hline$\%$ Primary graduate & 8.3 & 8.9 & 6.9 & 2.78 & 3.42 & 2.29 & 1.2 & 1.9 & 0.6 \\
\hline $\begin{array}{l}\% \text { Junior middle school graduate } \\
\% \text { Technical and specialized high }\end{array}$ & 59.8 & 58.6 & 63.1 & 35.08 & 40.48 & 30.81 & 22.8 & 26.3 & 18.9 \\
\hline school graduate & 9.6 & 8.8 & 11.8 & 9.43 & 10.42 & 8.71 & 8.4 & 8.7 & 8.2 \\
\hline$\%$ Senior middle school graduate & 14.3 & 15.1 & 12.3 & 31.20 & 23.51 & 37.11 & 26 & 22.7 & 29.2 \\
\hline$\%$ Vocational high school graduate & 4.4 & 4.8 & 2.9 & 9.04 & 9.38 & 8.82 & 12.9 & 11.8 & 14.3 \\
\hline$\%$ Vocational college graduate & 1 & 0.8 & 1.5 & 9.04 & 8.18 & 9.74 & 20.2 & 18.9 & 21.7 \\
\hline$\%$ University graduate & 0.3 & 0.4 & 0 & 2.84 & 3.72 & 2.18 & 8.1 & 9.4 & 6.9 \\
\hline$\%$ Post-graduate graduate & 0 & 0 & 0 & 0.06 & 0.15 & 0 & 0.2 & 0.1 & 0.2 \\
\hline \multicolumn{10}{|l|}{ Work History and Current Job } \\
\hline Years of workiexperience & 10.38 & 11.41 & 7.79 & 20.01 & 20.84 & 19.39 & 19.18 & 20.31 & 17.88 \\
\hline Years in agriculture & 4.48 & 4.97 & 3.11 & n/a & $\mathrm{n} / \mathrm{a}$ & $\mathrm{n} / \mathrm{a}$ & n/a & $\mathrm{n} / \mathrm{a}$ & $\mathrm{n} / \mathrm{a}$ \\
\hline No. of times changed danwei & 1.58 & 1.76 & 1.09 & $\mathrm{n} / \mathrm{a}$ & $\mathrm{n} / \mathrm{a}$ & $\mathrm{n} / \mathrm{a}$ & 0.78 & 0.81 & 0.75 \\
\hline \multicolumn{10}{|l|}{ Current/Latest Job Classification } \\
\hline$\%$ Cadre & 1.6 & 1.7 & 1.5 & n/a & $\mathrm{n} / \mathrm{a}$ & $\mathrm{n} / \mathrm{a}$ & n/a & $\mathrm{n} / \mathrm{a}$ & $\mathrm{n} / \mathrm{a}$ \\
\hline$\%$ Permanent & 2.9 & 2.7 & 3.5 & 70.53 & 69.51 & 71.22 & 58.4 & 59.9 & 56.6 \\
\hline$\%$ Contract & 33.3 & 32 & 36.5 & 28.63 & 30.19 & 27.52 & 39.7 & 38.7 & 40.9 \\
\hline$\%$ Temporary & 61.1 & 62.3 & 58.3 & 0.58 & 0.30 & 1.03 & 1.5 & 1.1 & 2.1 \\
\hline$\%$ Part-time & 0.3 & 0.4 & 0.2 & n/a & $\mathrm{n} / \mathrm{a}$ & $\mathrm{n} / \mathrm{a}$ & n/a & $\mathrm{n} / \mathrm{a}$ & $\mathrm{n} / \mathrm{a}$ \\
\hline
\end{tabular}




\begin{tabular}{|c|c|c|c|c|c|c|c|c|c|}
\hline \multicolumn{10}{|l|}{ Current position } \\
\hline$\%$. Upper-level cadre & 0.1 & 0 & 0.3 & 0.32 & 0.75 & & 1.7 & 2.1 & 1.4 \\
\hline$\%$ Middle-level cadre & 0.6 & 0.8 & 0.3 & 3.36 & 4.92 & 2.17 & 12.5 & 17 & 7.7 \\
\hline$\%$ Clerical/Office staff & 3.3 & 3.3 & 3.3 & 14.60 & 9.84 & 18.31 & 28.1 & 22.2 & 34.5 \\
\hline \% Engineer/Technician & 6.9 & 8.8 & 2 & 5.88 & 8.64 & 2.17 & 9.2 & 10.9 & 7.5 \\
\hline$\%$ Production line worker & 66.1 & 59.9 & 81.8 & 65.76 & 68.26 & 63.73 & 40.9 & 40.7 & 40.8 \\
\hline$\%$ Service worker & 12.2 & 13.5 & 8.8 & 6.59 & 4.17 & 8.47 & 3.9 & 3.7 & 4.1 \\
\hline$\%$ Sales staff & 0.3 & 0.4 & 0 & 2.39 & 2.53 & 2.29 & 1.6 & 1.7 & 1.5 \\
\hline \multicolumn{10}{|l|}{ Ownership of current/latest firm } \\
\hline$\%$ State & 77.9 & 83.8 & 63.5 & 81.33 & 85.74 & 78.00 & 80.9 & 85 & 76.4 \\
\hline$\%$ Collective & 12.1 & 12.4 & 11.4 & 10.54 & 7.06 & 13.13 & 11.7 & 9.3 & 14.3 \\
\hline \% Joint venture & 7.1 & 3 & 17.3 & 1.37 & 1.65 & 1.15 & 1.6 & 1.7 & 1.6 \\
\hline$\%$ Foreign invested & 0 & 0 & 0 & $\mathrm{n} / \mathrm{a}$ & $\mathrm{n} / \mathrm{a}$ & $\mathrm{n} / \mathrm{a}$ & 0.1 & 0.1 & 5.1 \\
\hline \% Joint stock & 0 & 0 & 0 & 4.81 & 4.05 & 5.41 & 3.9 & 2.8 & 2 \\
\hline$\%$ Private & 2.8 & 0.8 & 7.9 & 0.65 & 0.30 & 0.92 & 1.3 & 0.7 & 0.3 \\
\hline$\%$ Individual & 0 & 0 & 0 & 0.46 & 0.45 & 0.46 & 0.2 & 0.1 & 0.3 \\
\hline \multicolumn{10}{|l|}{ Tenure/Training at c/l firm } \\
\hline Tenure at current/latest firm (years) & 4.16 & 4.36 & 2.12 & 15.91 & 16.78 & 15.25 & 15.55 & 16.31 & 14.67 \\
\hline$\%$ Received training at $\mathrm{c} / \mathrm{l}$ firm. & 55.2 & 53.3 & 60.1 & 48.57 & 50.31 & 47.02 & 65.3 & 67.5 & 62.8 \\
\hline $\begin{array}{l}\text { Income and Welfare } \\
\text { Monthly income (current job for } \\
\text { migrants \& urban workers \& last job } \\
\text { before layoff for laid-off workers). }\end{array}$ & 558.97 & 598.35 & 457.05 & 412.36 & 425.85 & 402.37 & 552.68 & 575.77 & 528.25 \\
\hline Days worked per week & 5.98 & 6.09 & 5.71 & 5.45 & 5.48 & 5.44 & 5.32 & 5.39 & 5.26 \\
\hline Hours worked per day & 8.96 & 9.1 & 8.62 & 7.99 & 8.03 & 7.96 & 8.13 & 8.24 & 8.01 \\
\hline \multicolumn{10}{|l|}{ Payment Method } \\
\hline$\%$ Paid on piece rate & 36.3 & 26.7 & 60.8 & 7.67 & 7.21 & 7.94 & 9.1 & 9.5 & 8.9 \\
\hline$\%$ Paid on hourly rate & 22.6 & 26.2 & 13.5 & 4.78 & 4.60 & 4.93 & 10 & 8.3 & 11.5 \\
\hline$\%$ Paid on fixed wage & 36.2 & 41.4 & 22.9 & 85.80 & 86.66 & 85.20 & 77.4 & 78 & 77 \\
\hline \multicolumn{10}{|l|}{ Benefits } \\
\hline$\%$ Firms provide medical insurance & 20.3 & 23.5 & 12.1 & 53.77 & 59.00 & 49.77 & 50.3 & 53.5 & 47.1 \\
\hline$\%$ Firms provide pension & 14.1 & 14.5 & 13.1 & 76.15 & 78.61 & 74.37 & 87.9 & 88.8 & 87.1 \\
\hline$\%$ Firms provide unemploy. ins. & 7.8 & 8.8 & 5.2 & 37.79 & 41.00 & 35.37 & 59 & 59.1 & 44.4 \\
\hline
\end{tabular}




\section{Sample Characteristics}

Selected sample means and proportions from the worker surveys are reported in Table 1 which reveals marked gender differences in the sample composition--men make up 52 of our sample of employed urban residents and 72 percent of migrants but only 44 percent of laid-off urban workers. The laid off-workers, at a mean age of 39, are on average a year older than their employed urban counterparts and 11 years older than migrant workers who are 38 and 28 years of age, respectively. Urban residents stay in school longer than migrants - employed residents have a mean of 11.7 years of schooling (laid-off urban residents have a mean of 10.6 years of schooling) in comparison to the migrants' mean of 9 years. Over 8 percent of the urban workers and 2.8 percent of the laid-off workers have university educations while this level of educational attainment is almost non-existent amongst the migrants. Although the majority of workers received some job training, the proportion of employed urban residents receiving such training was 10 percentage points greater than the proportion of migrants and almost 17 percentage points higher than those urban residents who were laid-off.

The monthly income reported in Table 1 includes wages, subsidies, and bonuses but does not include the value of employer-provided benefits such as medical insurance, pension accruals, and housing. It is interesting to note that the pecuniary income of the migrants (559 yuan/month) slightly exceeds that of the urban workers (553 yuan/month) and considerably exceeds the pre-layoff income of the laid-off workers (412 yuan/ month). The high monthly income of the migrants is due in large part to hours worked by male migrants who tend to work 9 hours a day and 6 days a week. The income of the laid-off workers reported in Table 1 refers to their average monthly income in the last job 
before layoff. It has been adjusted to 1999 equivalents by means of an urban consumer price index (Zhongguo tongji nianjian, p.290). Over one third of the laid-off workers (37.7 percent) managed to find some type of work after being laid off and 27.4 percent reported still having a job at the time of the survey. The average monthly income declared by these re-employed workers at 571 yuan/month exceeds that of their continuously-employed urban counterparts. However, they work more hours per day (8.46) and more days per week (5.68) than urban workers who have never experienced a layoff (but less hours per week than migrants). Consequently, their hourly wage at 2.58 yuan is higher than that received by migrants (2.44 yuan/hour) and lower than that received by their urban counterparts (2.93 yuan/hour).

In this sample, approximately 80 percent of the urban residents (both the employed and the laid off) work (or used to work) for state-owned enterprises. This proportion exceeds the national proportion of urban workers employed in state-owned enterprises by $9 \%$ (Zhongguo laodong tongji nianjian, p.14) and is an artifact of the sampling procedure that was aimed in part towards surveying large numbers of laid-off urban workers. Fully 78 percent of the migrants work at state-owned enterprises with a further 12 percent employed by collectively-owned enterprises. These migrants are quite settled-average tenure at their current enterprise exceeds 4 years even though the lion's share of migrants, 61 percent, were classified as "temporary" workers. In contrast, 57 percent of employed urban workers and (ironically) 71 percent laid-off urban residents were considered "permanent" workers.

Far fewer of the laid-off workers than the continuously employed report their latest job to be one from the higher rungs of the occupational scale-cadres, 
office/clerical workers, and engineers and technicians. The opposite is true for jobs at the lower rungs - higher proportions of the laid-off workers than those never laid off used to be production line workers, service workers, and sales workers. Interestingly, the proportions of migrants and laid-off urban workers reporting themselves as production line workers (66 percent) are equal. Migrants are reputed to take the jobs that urban residents disdain but in this sample, which contains many enterprises that both hire migrants and lay-off urban residents, we see that migrants have similar occupations to those being laid-off.

There is a great deal of difference in the method by which workers are paid. 36 percent of migrants were on piece rate, 23 percent were paid by the hour, and 36 percent had fixed wages. Over 77 percent of employed urban workers received fixed wages, 9 percent were on piece rate and approximately 10 percent were paid on an hourly basis. At their latest job before being laid off, 86 percent of laid-off workers received fixed wages, 8 percent were paid by piece rate and 5 percent were compensated on an hourly basis. 86 percent of employed urban workers received pension benefits while only 14 percent of migrants did. Medical insurance was provided by employers to 49 percent of urban workers. Only 20 percent of migrant workers received this benefit. (58 percent of the laid-off workers used to receive medical insurance.) 
Table 2: A Comparison of the Pre- and Post- Lay Off Incomes and Working Conditions for Re-Employed Workers

\section{Pre-Lay Off Situation}

Income and Hours of Work

Monthly Income

Hours worked/day

Days worked/week

\section{Payment Method \\ $\%$ Paid by piece rate \\ $\%$ Paid an hourly rate \\ $\%$ Paid fixed salary \\ $\%$ Other}

\section{Occupation}

Upper-level cadre

Middle-level cadre

office staff

engineers and technicians

production worker

service worker

salesperson

self employed

other

\section{Benefits Provided}

$\%$ Firms provide medical ins.

$\%$ Firms provide pension

$\%$ Firms provide unemploy. ins.

\section{Re-Employment Situation}

\section{All Male Female}

$\begin{array}{rrrl}438.36 & 456.93 & 427.98 & \text { Monthly Income } \\ 7.96 & 8.01 & 7.93 & \text { Hours worked/day }\end{array}$

$\begin{array}{llll}5.45 & 5.45 & 5.47 & \text { Days worked/week }\end{array}$

$\begin{array}{rrrl}9.42 & 8.12 & 9.97 & \text { \% Paid by piece rate } \\ 7.41 & 5.58 & 8.64 & \text { \% Paid an hourly rate } \\ 80.76 & 83.25 & 79.40 & \text { \% Paid fixed salary } \\ 2.40 & 3.05 & 1.99 & \text { \% Other }\end{array}$

$\mathrm{n} / \mathrm{a}$

$\begin{array}{rrrl}0.19 & 0.49 & & \text { n/a } \\ 3.85 & 5.91 & 2.54 & \text { manager } \\ 14.45 & 11.33 & 16.51 & \text { office staff } \\ 5.97 & 9.36 & 3.81 & \text { n/a } \\ 66.09 & 65.52 & 66.35 & \text { ordinary worker } \\ 5.59 & 3.94 & 6.66 & \text { service worker } \\ 2.89 & 2.46 & 3.18 & \text { sales worker } \\ \mathrm{n} / \mathrm{a} & \mathrm{n} / \mathrm{a} & \mathrm{n} / \mathrm{a} & \text { self employed } \\ 0.96 & 0.99 & 0.95 & \text { other }\end{array}$

$\begin{array}{lll}62.99 & 70.62 & 58.16\end{array}$

$\begin{array}{lll}83.82 & 86.77 & 82.19\end{array}$

$39.96 \quad 44.57 \quad 37.05$
$\%$ Firms provide medical ins.

$\%$ Firms provide pension

$\%$ Firms provide unemploy. ins.
All

Male Female

$\begin{array}{rrr}571.04 & 627.13 & 535.16 \\ 8.46 & 8.80 & 8.23 \\ 5.68 & 5.87 & 5.57\end{array}$

25.58

14.68

46.54

13.21

17.19

12.50

47.40

22.92

30.99

16.20

46.13

6.69

$\begin{array}{rrr}\mathrm{n} / \mathrm{a} & \mathrm{n} / \mathrm{a} & \mathrm{n} / \mathrm{a} \\ 13.96 & 14.77 & 13.52 \\ 5.84 & 4.70 & 6.56 \\ \mathrm{n} / \mathrm{a} & \mathrm{n} / \mathrm{a} & \mathrm{n} / \mathrm{a} \\ 50.51 & 47.65 & 52.05 \\ 13.71 & 10.07 & 15.98 \\ 6.09 & 6.04 & 6.15 \\ 6.85 & 13.42 & 2.87 \\ 3.05 & 3.36 & 2.87\end{array}$

$\begin{array}{lll}31.95 & 29.79 & 33.45\end{array}$

$\begin{array}{lll}44.23 & 38.80 \quad 47.89\end{array}$

$26.98 \quad 25.00 \quad 28.23$ 
Table 2 (Cont.): A Comparison of the Pre- and Post- Lay Off Incomes and Working Conditions for Re-Employed Workers

\section{Pre-Lay Off Situation}

Ownership Structure of Employer

\section{$\%$ state}

$\%$ collective

$\%$ joint-venture

$\%$ foreign owned

$\%$ joint-stock

$\%$ private

$\%$ individual

$\%$ other

$\%$ don't know

\section{Re-Employment Situation}

\section{All Male Female}

$77.22 \quad 84.65$

$12.36 \quad 7.43$

$1.74 \quad 1.98$

72.70

15.24

$\begin{array}{rr}1.74 & 1.98 \\ \mathrm{n} / \mathrm{a} & \mathrm{n} / \mathrm{a}\end{array}$

$\begin{array}{ll}4.25 & 2.48\end{array}$

$1.54 \quad 0.50$

1.59

$\mathrm{n} / \mathrm{a}$

5.40

2.22

0.63

$\begin{array}{lll}1.93 & 1.49 & 2.22\end{array}$

$\mathrm{n} / \mathrm{a} \quad \mathrm{n} / \mathrm{a}$

n/a \% don't know

$\%$ state

$\%$ collective

$\%$ joint-venture

$\%$ foreign owned

$\%$ joint-stock

$\%$ private

$\%$ individual

$\%$ other

naire.
All Male Female

$\begin{array}{lll}37.37 & 34.90 & 39.02\end{array}$

$\begin{array}{lll}5.56 & 6.04 & 5.28\end{array}$

$\begin{array}{lll}5.81 & 6.04 & 5.69\end{array}$

$\begin{array}{lll}1.52 & 2.01 & 1.22\end{array}$

$\begin{array}{lll}8.33 & 6.71 & 9.35\end{array}$

$\begin{array}{lll}15.91 & 9.40 & 19.92\end{array}$

$20.20 \quad 26.17 \quad 16.26$

$\begin{array}{lll}4.04 & 7.38 & 2.03\end{array}$

\begin{tabular}{lll}
1.26 & $1.34 \quad 1.22$ \\
\hline
\end{tabular} 


\section{A Comparison of the Pre- and Post-Lay Off Experiences of Re- Employed Workers}

As described above, slightly over one third of the laid-off workers in our sample had found some form of employment by the time of the survey and approximately one quarter of the laid-off workers reported still having a job. This group of re-employed workers is of particular interest as it allows comparisons of the workers' pre- and postlayoff work experiences.

Table 2 reveals these re-employed workers are earning more in their new positions than they did in the last job before being laid off. (Recall that the pre-layoff incomes have been adjusted to 1999 yuan.) They work longer days and more days per week for their post-layoff employers. The increase in work hours is more pronounced for men than for women. The percentage of workers being paid fixed salaries instead of hourly or piece rates has dropped quite dramatically from over 80 percent to 47 percent. The fraction of workers being paid on a piece-rate basis almost tripled.

Unfortunately, the survey instrument failed to offer identical choices when eliciting information about occupational classification in the pre- and post-lay off situations. It appears, however, from the information summarized in Table 2 that some workers have moved out of production and office staff positions and into sales and service positions. Interestingly, some workers seem to have moved up the occupational ladder - the percentage of managers in the post-layoff column of Table 2 exceed the combined percentages of cadres and engineers/technicians in the pre-layoff column. As might be expected, there has been a pronounced drop in the provision of benefits. The 
percentage of workers receiving medical insurance and pensions from their firms has been cut in half.

The ownership structure of employers is decidedly different in the pre- and postlayoff worlds. In the past, over 77 percent of these re-employed workers were employed by state-owned enterprises, that percentage has fallen to only 37 percent in their new positions. Many of these laid-off workers are now either working in private firms (16 percent) or are self-employed (getihu) (20 percent).

\section{Empirical Analysis}

\section{Returns to Education}

China's pre-reform labor system was the antithesis of a free market. The state claimed ownership of labor services and bureaucratically assigned workers to enterprises for life. Workers' preferences concerning occupation or location mattered little. On the enterprise side, managers for the most part had to accept any and all workers allocated to them. Pay rates were nearly equal regardless of worker effort, productivity, or performance. This system was incompatible with the economic reform program.

Manager's demands for a more flexible and efficient labor system were often initially resisted and then introduced only little by little. Yet even these initial, tentative steps toward market rationalization rapidly yielded profound changes in China's labor system. Workers gained a great deal of freedom to choose where and for whom they would work. A vibrant private sector emerged in which managers had the right to determine the size and composition of their work force. There was a strong movement towards decentralized, productivity-determined remuneration. Wage variation across 
workers and sectors increased relative to the pre-reform period (Maurer-Fazio et al. 1999). Chinese workers experienced considerable change in their work environment. Given the incursion of market forces into the urban Chinese workplace by the late 1990s, it seems likely that we would observe market-influences on returns to investments in schooling. To the extent that the work place exhibits features of both the legacy of its pre-reform assignment and reward system and the post-reform market system, it is possible that the returns to education vary according to the degree of marketization. We thus hypothesize that the returns to education will be higher for the labor market participants who have obviously found their jobs in the reform period - the re-employed workers. We also hypothesize that workers who find their jobs through a competitive market means (as opposed to those who obtained their jobs through a non-market, uncompetitive mechanism) will have greater rewards to their human capital in general, and to their schooling in particular.

The methodology employed here involves estimating earnings functions of the basic form originated by Mincer (1974). The dependent variable in the underlying regressions is the natural log of hourly earnings, which include wages, subsidies, and bonuses but do not take into account employer-provided benefits such as medical insurance, pension accruals, or housing. The independent variables include years of schooling, years of work experience, party membership, marital status, city of residence, enterprise ownership sector, health status, payment method, and gender. The return to education is calculated and expressed in percentage terms by taking the coefficient on years of schooling from the Mincerian earnings function and multiplying it by 100 . 
Table 3--Rates of Return to Years of Formal Schooling in Urban Chinese Labor Markets 1999-2000

\section{Type of Worker}

\section{Employed Urban Residents}

All Urban Workers

Urban Males

Urban Females

Urban Workers $>12$ years of schooling

Urban Workers $<=12$ years of schooling

Urban Workers--competitively found jobs

Urban Workers assigned jobs
Returns* Significance No.of Obs.

$\begin{array}{llc}3.70 & 0.000 & 1546 \\ 4.50 & 0.000 & 795 \\ 2.60 & 0.000 & 751 \\ 3.80 & 0.032 & 529 \\ 3.60 & 0.000 & 1017 \\ 5.50 & 0.000 & 452 \\ 3.10 & 0.000 & 1088\end{array}$

Migrant Workers

All Migrant Workers

$\begin{array}{lll}1.50 & 0.040 \quad 1101\end{array}$

$\begin{array}{lll}1.00 & 0.256 \quad 783\end{array}$

$\begin{array}{lll}4.90 & 0.000 & 318\end{array}$

$\begin{array}{lll}6.40 & 0.004 & 351\end{array}$

$\begin{array}{lll}1.00 & 0.182 & 750\end{array}$

$2.10 \quad 0.118 \quad 261$

$\begin{array}{lll}1.20 & 0.172 \quad 816\end{array}$

Migrant Workers--competitively found jobs
Migrant Workers introduced to their jobs

Laid-off Urban Residents (based on pre-layoff income)

$\begin{array}{llll}\text { All laid-off } & 3.00 & 0.000 & 918 \\ \text { Laid-off males } & 3.70 & 0.000 & 377 \\ \text { Laid-off females } & 2.80 & 0.005 & 540 \\ \text { Laid-off >12 years of schooling } & 7.99 & 0.064 & 126 \\ \text { Laid-off <=12 years of schooling } & 2.40 & 0.010 & 792 \\ \text { Laid-off -- competitively found jobs } & 1.10 & 0.352 & 276 \\ \text { Laid-off -- introduced to jobs } & 3.90 & 0.000 & 615\end{array}$

Re-employed urban residents (laid-off workers with new jobs, based on current job income)

All Re-emplyed Workers

Re-employed Males

4.60

0.001

338

Re-employed Females

7.10

0.001

129

3.40

0.082

209

Re-employed Workers $>12$ years of schooling

1.90

0.747

55

Re-employed Workers <= 12 years of schooling

3.10

0.135

283

Re-employed Workers--competitively found jobs

11.70

0.024

70

Re-employed Workers introduced to their jobs

4.60

0.003

258

$\begin{array}{lccc}\text { Re-employed urban residents (based on pre-layoff income) } & & \\ \text { All Re-emplyed Workers } & 2.80 & 0.018 & 270 \\ \text { Re-employed Males } & 4.56 & 0.029 & 104 \\ \text { Re-employed Females } & 2.17 & 0.147 & 166 \\ \text { Re-employed Workers > 12 years of schooling } & 4.63 & 0.427 & 42 \\ \text { Re-employed Workers <= 12 years of schooling } & 3.91 & 0.022 & 228 \\ \text { Re-employed Workers--competitively found jobs } & 4.96 & 0.384 & 117 \\ \text { Re-employed Workers introduced to their jobs } & 3.20 & 0.010 & 238\end{array}$


Table 3 Continued

Type of Worker

Laid-off Workers still without jobs (based on pre-layoff income)

All non-rehired

Non-rehired males

Non-rehired females

Non-rehired $>12$ years of schooling

Non-rehired $<=12$ years of schooling

Non-rehired --competitively found jobs

Non-rehired -- introduced to jobs
2.70

2.77

2.80

\section{Returns* Significance No.of Obs.}

3.90

1.10

0.20

3.80

0.025

556

244

311

77

479

159

379

Data Source: China Labor Market Integration Project

${ }^{*}$ Returns to schooling here are expressed as percentages which are calculated as the coefficients on years of schooling in the Mincerian earnings functions multiplied by 100 .

Note: The dependent variable in the underlying regressions is the natural log of hourly earnings which include wages, subsidies, and bonuses but do not take into account employer-provided benefits such as medical insurance, pension accruals, or housing. The independent variables include years of schooling, years of work experience, party membership, marital status, city of residence, enterprise ownership sector, health status, payment method and gender.

Results

Table 3 reports the returns to schooling for well-defined sets of workers in China's urban labor markets. The first panel of results reports returns to education for the continuously-employed urban residents in our sample (that is, those not laid off by the firms that anchor the surveys). This set of workers is then divided first by gender, then by education level (high vs. low), and finally by whether the workers used a clearly competitive method to find their jobs as opposed to being either assigned to their position or being introduced by family members.

The coefficients on years of schooling in the underlying regressions were statistically significant for each of the groups in this first set. As revealed in Table 3 the returns vary from a low of 2.6 percent for the never laid-off females to a high of 5.5 percent to those who report using competitive methods to find their jobs. The returns for 
the group as a whole were 3.7 percent. This overall rate of return appears low, and given the nature of this sample with its relatively high proportion of state-sector employees and over sampling of firms engaged in layoffs, this result is not altogether surprising.

However, we still see an increase in the returns to education relative to the pre-reform period. In our sample urban males received an increase in income of 4.5 percent for each incremental year of schooling. We can compare this to a rate of return of 2.5 percent for men in the state sector reported by Meng and Kidd (1997). Since industrial reform did not significantly influence urban enterprises until 1984, their estimates for 1981 can be considered as yielding returns to education in the pre-reform era.

The second panel of results in Table 3 reports the returns to education for migrant workers, which differ considerably from those of the continuously-employed urban workers. The returns to schooling for migrants, as a whole, is very low- -1.5 percent. Only two of the sub-groups of migrants have rates of return to schooling that are statistically significant--both are interesting. First, women migrants have a return of 4.9 percent (while men's returns are not statistically different from zero.). And second, migrants with more than the mean 9 years of schooling have a very high rate of return to schooling-6.4 percent.

The third panel of Table 3 reports the returns to education received by the laid-off workers in their last job before being laid off. The coefficients on years of schooling in the underlying regressions were statistically significant for all but one of the sub-groups in this panel - those who found their jobs through a competitive mechanism. The returns, in general, are somewhat lower for this group of workers than for the continuouslyemployed urban workers. The exceptions are interesting - the group of workers with 
higher-than-typical educations, those with more than 12 years of schooling, found their human capital well rewarded. Each additional year of schooling increased their income by 8 percent. The laid-off workers have an average of 20 years work experience and many were considered permanent (as opposed to contract) workers. These facts imply that many of the laid-off workers were hired by their enterprises in the pre-reform era. It is thus not surprising then that the returns to education are higher for those assigned to their jobs (3.9 percent) than for those who found their job by a competitive means (not significantly different from 0 ). In the pre-reform period it was the norm for students to be assigned to their jobs by the government or by labor bureaus. Job searches were frowned upon — students waited to be assigned jobs. State-sector employees requesting a transfer were viewed with suspicion as being either incompetent or having interpersonal problems

The fourth panel of Table 3 deals with a subset of the laid-off workers - those who managed to find new jobs after being laid off. The rewards to human capital accumulation are greater for this group of urban workers (in arguably the most competitive sphere of China's labor system) than for those never laid off. The return to a year of schooling for the group, based on the income at the new job, is 4.6 percent with male rehired workers realizing a return of 7.1 percent and women 3.4 percent. Those who reported using a clearly competitive method of finding work have a remarkable return of 11.6 percent to an additional year of schooling. The fifth panel is similar to the third in that it considers the returns to education for laid-off workers in their last job before being laid-off but is drawn from a restricted subset - those re-employed at the time of the survey. This comparison allows us to avoid the issues of unobserved ability and productive characteristics - we are using the same individuals with the same observed 
and unobserved characteristics. Comparison of the fourth and fifth panels suggests that education and human capital is better rewarded in the more competitive sectors of China's current urban economy than it was in the past. This result accords with that of Liu, Meng, and Zhang (2000) who find that the increasing marketization of the Chinese economy increases competition and drives employers to reward productivity-related characteristics more than before.

The final panel of Table 3 reports returns of education for the other sub-set of the laid-off workers - those who remain unemployed. Comparing these results to those based on the pre-layoff income of those who found new jobs we can see that the overall rate of return to education is quite similar for the two subsets of laid-off workers. The significant difference here is gender related. The men who were re-hired had higher rates of return to education in their pre-layoff jobs than those who have not secured subsequent employment - the opposite is true for the women. The women who haven't found subsequent employment had a higher rate of return to education than those who have found new jobs.

Table 4: $\quad$ Oaxaca/Blinder Decomposition of Total Wage Differentials and Education's Contribution to the Wage Gaps

Urban workers as base, in comparison with:

\begin{tabular}{|c|c|c|}
\hline $\begin{array}{c}\text { Migrant } \\
\text { workers }\end{array}$ & $\begin{array}{l}\text { Laid-off } \\
\text { workers }\end{array}$ & $\begin{array}{l}\text { Rehired } \\
\text { workers }\end{array}$ \\
\hline 2.438 & 2.237 & 2.576 \\
\hline $83.29 \%$ & $76.43 \%$ & $88.01 \%$ \\
\hline 0.4899 & 0.6897 & 0.3503 \\
\hline 75.11 & 39.74 & -8.48 \\
\hline 24.88 & 60.25 & 108.48 \\
\hline
\end{tabular}

Contribution of education to total wage gap $\%$ Due to differences in endowments 
Migrant workers as base, in comparison with:

Average hourly wage
Wage ratio ( /migrant)
Total Wage Differential
(yuan/hour, in absolute value)
$\%$ Explained
$\%$ Unexplained

Average hourly wage

Unexplained
Urban

workers

2.927

120.06

0.4889

5.89

94.11
Laid-off

workers

2.237

$91.76 \%$

2.576

$105.66 \%$

0.1386

90.56

9.44

Contribution of education to total wage gap $\%$ Due to differences in endowments

17.21

$-20.38$

35.81

Note: The hourly wage rate used in the underlying regressions for laid-off workers is calculated from laid-off workers' reported monthly income from last job before lay-off (adjusted to 1999 yuan by an urban consumer price index). The hourly wage rate for all other groups is calculated from reported monthly income at current job.

Wage Differentials

We use the well-known procedure developed by Oaxaca (1973) and Blinder (1973) to analyze the composition of the wage gaps between the various groups in China's urban labor markets. This procedure splits the total wage differential into two components: that part of the differential attributable to differences in observable productive characteristics (e.g., education), and the residual gap attributable to differences in the returns to these productive characteristics. This residual, or unexplained, component of the wage gap is generally attributed to discrimination, but could be also due to differences in unobserved productive characteristics.

Table 4 reports the results of the Oaxaca/Blinder decompositions. The top panel refers to the earnings differentials between the employed urban workers and migrants, laid-off urban workers, and re-employed workers, respectively. The second panel refers 
to the earnings differentials between migrant workers and the urban, laid-off, and reemployed workers, respectively.

When we use urban workers as the basis of comparison, that is, when we value the endowments of the groups according to the urban workers' reward structure, we see that differences in productive characteristics between migrants and urban workers accounts for 75 percent of their pay differences. We also see in particular, that differences in educational attainment account for 52 percent of the total wage gap. In contrast, only 40 percent of the wage gap between urban workers and laid-off urban residents can be explained by differences in productive characteristics - 60 percent remains unexplained. Of course, a part of this differential may be caused by a downward bias in the laid-off workers recall of their monthly income before being laid off. When we compare the current incomes of urban workers with those of the laid-off but subsequently re-employed we see that the entire wage gap (and then some) remains unexplained by differences in observed characteristics. Re-employed workers are receiving very different treatment than continuously-employed urban workers. The contribution of differences in educational endowments to explaining the total wage gap between urban residents and laid-off workers and re-employed workers is 16 and 28 percent, respectively.

Looking at the second panel of Table 4, that is, using migrant workers as the base of the comparisons and valuing the endowments of the other groups according to the migrant workers' reward structure we see that the lion's share of the earnings differential between migrants and urban residents (94 percent) remains unexplained by differences in productive characteristics. This result is not surprising given that the work and remuneration conditions that migrants face and their disadvantaged position vis-à-vis 
those with urban-hukou status. Even though migrants may be making rational economic decisions in migrating to urban areas, that is, they may have increased their income and well being relative to their pre-migration situation ${ }^{3}$ they are paid a wage far below their marginal product (Dinh 2002, Meng 2002, Knight, Song, \& Jia 1999). ${ }^{4}$ When we compare the earnings differentials between the migrants and the laid-off workers we see that 77 percent of the gap remains unexplained and that education's contribution to the explained portion is negative.

The final decomposition, between the migrants and re-hired urban workers, is perhaps the most significant. Here we have two groups of workers forced to seek work in an environment largely unprotected by the institutional legacy of the past. Here the earning gap is small: the re-employed workers earn only 6 percent more than the migrants (on an hourly basis) and 91 percent of that difference is explained by differences in productive characteristics. Differences in educational endowments account for 36 percent of the total earnings differential.

\section{Conclusion}

Our empirical results demonstrate that hukou status continues to influence labor market earnings: the human capital of urban residents is better rewarded than that of migrant workers. However, urban residents should no longer be considered as just one entity. There are clearly reform winners and losers amongst urban residents. Generally speaking, workers who found their current employment after being laid-off face a much

\footnotetext{
${ }^{3}$ The migrants in this sample report much higher degrees of job satisfaction than their employed urban counterparts.

4 Dinh (2002) and Meng (2002) both examine the relative productivity of urban and migrant workers in this data set and report that migrants are paid a fraction of their marginal product while urban workers are paid more than their marginal product. Knight, Song, and Jia report a similar result based on a 1995 enterprise-based sample of migrants.
} 
more competitive environment than they did in the past. It is significant that the human capital accumulation of this group of workers is better rewarded, in terms of incremental earnings for each additional year of schooling, than that of continuously-employed urban workers. Interestingly, the education of the group of re-employed workers is also better rewarded in these workers' post-layoff jobs than it was in their pre-layoff jobs.

An interesting hierarchy of returns to education has developed. The education of migrants is poorly rewarded in general, although, admittedly, both women migrants and migrants with more than middle-school educations have high returns. The continuouslyemployed urban residents fill the next rank with moderate returns to education. Reemployed urban residents experience the highest rewards to their education, especially those who used a competitive means to find their post-layoff employment.

When we assess the earning differentials between groups using the continuouslyemployed urban residents as the basis of comparison we can explain 75 percent of the earnings gap for migrants, 40 percent of gap for laid-off workers, and -8 percent of the earnings gap for the re-employed workers in terms of differences in productive characteristics. When we use the reward structure of migrants as the basis of comparison we can explain from as little as 6 percent of the earnings differentials between migrants and urban residents to as much as 91 percent of the difference in earnings between migrants and the re-employed urban workers. Educational attainment remains an important explanator of earnings differentials between institutionally-differentiated groups of workers in China's urban labor markets. 


\section{References}

Appelton et al. 2002. "Labour Retrenchment in China: Determinants and Consequences," China Economic Review. Volume 13, No.2, pp. 252-275.

Blinder, Alan S. 1973. "Wage Discrimination: Reduced Form and Structural Estimates," Journal of Human Resources. Volume 18, No. 4. pp. 436-455.

Chan, Kam Wing and Zhang, Li. 1999. "The Hukou System and Rural-Urban Migration in China: Processes and Changes," The China Quarterly. Issue 160. December. pp.818-855.

Cook, Sarah and Maurer-Fazio, Margaret eds. 1999. The Workers' State Meets the Market: Labour In China's Transition. London: Frank Cass.

Dinh, Ngan. 2002. Migrant Workers in Chinese Urban Enterprises: 20 Years After Reforms. Thesis: Bates College, Department of Economics.

Fan, C. Cindy. 1999. "Migration in a Socialist Transitional Economy: Heterogeneity, Socioeconomic and Spatial Characteristics of Migrants in China and Guangdong Province," International Migration Review. Volume 33, No. 4. pp. 954-987.

Fan, C. Cindy. 2001. "Migration and Labor-Market Returns in Urban China: Results from a Recent Survey of Guangzhou," Environment and Planning. Volume 33. pp.479-508.

Fan, C. Cindy. 2002. "The Elite, the Natives, and the Outsiders: Migration and Labor Market Segmentation in Urban China," Annals of the Association of American Geographers. Volume 92. No. 1. pp.103-124.

Li,Ning. 1998. "Re-employment: A Solemn Scheme in 1998”, Beijing Review, May 1824, pp.9-13.

Li, Ning. 1997. "Promising Reemployment Project”, Beijing Review, August 18-24, pp.913.

Liu, Pak-Wai, Meng, Xin, and Zhang, Junsen. 2000. "The Impact of Economic Reform on Gender Wage Differentials and Discrimination in China" Journal of Population Economics. May. Volume 13(2) pp.331-52.

Knight, John, Song, Lina, and Jia, Huabin. 1999. "Chinese Rural Migrants in Urban Enterprises: Three Perspectives," in Sarah Cook and Margaret Maurer-Fazio eds. The Workers' State Meets the Market: Labour In China's Transition. London: Frank Cass. 
Maurer-Fazio, Margaret. (forthcoming). "The Role of Education in Determining Labor Market Outcomes in Urban China," in Emily Hannum and Albert Park edited Education and Reform in China (Provisional title). Cambridge: Harvard University Press, Modern China Series.

Maurer-Fazio, Margaret, Rawski, Thomas, and Zhang, Wei. 1999. "Inequality in the Rewards for Holding Up Half the Sky: Gender Wage Gaps in China's Urban Labour Market, 1988-1994" The China Journal No. 41, January. pp.55-88.

Meng, Xin. 2001. "Economic Restructuring and Income Inequality in Urban China," unpublished manuscript, Research School of Pacific and Asian Studies, Australian National University.

Meng, Xin. 2002. "Are Rural Migrants Outsiders In Chinese Urban Enterprises?-An Alternative Interpretation For The Earnings Gap Between Urban Workers And Rural Migrants," unpublished manuscript, Research School of Pacific and Asian Studies, Australian National University.

Meng, Xin and Kidd, Michael. 1997. "Labor Market Reform and the Changing Structure of Wage Determination in China's State Sector during the 1980s," Journal of Comparative Economics. Volume 25 No.3. pp.403-21.

Meng, Xin. and Zhang, Junsen. 2001. "Two-Tier Labor Market in Urban China: Occupational Segregation and Wage Differentials between Urban Residents and Rural Migrants in Shanghai," Journal of Comparative Economics. Volume 29, No.3, pp. 485-504.

Mincer, Jacob. 1974. Schooling, Experience and Earnings. New York: Columbia University Press.

Oaxaca, Ronald. 1973. "Male-Female Wage Differentials in Urban Labor Markets," International Economic Review, Volume 14, No. 3, pp. 693-709.

Roberts, Kenneth. D. 2001. "The Determinants of Job Choice by Rural Labor Migrants in Shanghai," China Economic Review. Volume 12. No. 1. pp.15-39.

Rural Development Institute, Chinese Academy of Social Sciences. 1998, 1997-98: Zhongguo nongcun jingji xingshe fenxi yu yuce [China's rural economic situation - analysis and forecast 1997-98] Beijing: Shehui kexue wenxian chubanshe.

Zhongguo laodong tongji nianjian [China Labour Statistical Yearbook] Beijing: Zhongguo tongji chubanshe, 1998, 2000.

Zhongguo tongji nianjian [China Statistical Yearbook] Beijing: Zhongguo tongji chubanshe, 2000 


\section{DAVIDSON INSTITUTE WORKING PAPER SERIES - Most Recent Papers}

The entire Working Paper Series may be downloaded free of charge at: www.wdi.bus.umich.edu

CURRENT AS OF 10/30/02

\begin{tabular}{|c|c|c|}
\hline Publication & Authors & Date \\
\hline $\begin{array}{l}\text { No. 508: Differential Rewards to, and Contributions of, Education in } \\
\text { Urban China's Segmented Labor Markets }\end{array}$ & $\begin{array}{l}\text { Margaret Maurer-Fazio and Ngan } \\
\text { Dinh }\end{array}$ & June 2002 \\
\hline $\begin{array}{l}\text { No. 507: Balassa-Samuelson Effect in Transition Economies: The Case } \\
\text { of Slovenia }\end{array}$ & Boštjan Jazbec & Oct. 2002 \\
\hline $\begin{array}{l}\text { No. 506: Explaining Gender Differences in Unemployment with Micro } \\
\text { Data on Flows in Post-Communist Economies }\end{array}$ & $\begin{array}{l}\text { Jana Stefanová Lauerová and } \\
\text { Katherine Terrell }\end{array}$ & Sep. 2002 \\
\hline No. 505: Bank Performance in Transition Economies & $\begin{array}{l}\text { Steven Fries, Damien Neven and } \\
\text { Paul Seabright }\end{array}$ & Sep. 2002 \\
\hline $\begin{array}{l}\text { No. 504: Does the Balassa-Samuelson Hypothesis Hold for Asian } \\
\text { Countries? An Empirical Analysis using Panel Data Cointegration Tests }\end{array}$ & Imed Drine and Christophe Rault & Sep. 2002 \\
\hline No. 503: Job Growth in Early Transition: Comparing Two Paths & $\begin{array}{l}\text { Štěpán Jurajda and Katherine } \\
\text { Terrell }\end{array}$ & Aug. 2002 \\
\hline $\begin{array}{l}\text { No. 502: Job Creation, Destruction and Transition in Poland, 1988- } \\
\text { 1998: Panel Evidence }\end{array}$ & $\begin{array}{l}\text { John E. Jackson and Bogdan } \\
\text { Mach }\end{array}$ & June 2002 \\
\hline $\begin{array}{l}\text { No. 501: Competition, Innovation and Growth in Transition: Exploring } \\
\text { the Interactions between Policies }\end{array}$ & $\begin{array}{l}\text { Philippe Aghion, Wendy Carlin } \\
\text { and Mark Schaffer }\end{array}$ & Mar. 2002 \\
\hline No. 500: Women in the LAC Labor Market: The Remarkable 1990's & $\begin{array}{l}\text { Suzanne Duryea, Alejandra Cox } \\
\text { Edwards and Manuelita Ureta }\end{array}$ & June 2001 \\
\hline $\begin{array}{l}\text { No. 499: Human Capital, Growth and Inequality in Transition } \\
\text { Economies }\end{array}$ & Michael Spagat & July 2002 \\
\hline No. 498: Understanding Czech Long-Term Unemployment & $\begin{array}{l}\text { Štěpán Jurajda and Daniel } \\
\text { Münich }\end{array}$ & Aug. 2002 \\
\hline $\begin{array}{l}\text { No. 497: Rent Seeking and Government Ownership of Firms: An } \\
\text { Application to China's Township-Village Enterprises }\end{array}$ & Jiahua Che & Sep. 2002 \\
\hline No. 496: Labor Market Flexibility in Central and East Europe & Jan Svejnar & Aug. 2002 \\
\hline $\begin{array}{l}\text { No. 495: When Information Dominates Comparison: A Panel Data } \\
\text { Analysis Using Russian Subjective Data }\end{array}$ & Claudia Senik & May 2002 \\
\hline No. 494: Corruption and Cross-Border Investment: Firm Level Evidence & $\begin{array}{l}\text { Beata K. Smarzynska and Shang- } \\
\text { Jin Wei }\end{array}$ & Aug. 2002 \\
\hline $\begin{array}{l}\text { No. 493: Modeling Sequences of Long Memory Positive Weakly } \\
\text { Stationary Random Variables }\end{array}$ & Dmitri Koulikov & Aug. 2002 \\
\hline $\begin{array}{l}\text { No. 492: Effects of Ownership and Financial Status on Corporate } \\
\text { Environmental Performance }\end{array}$ & $\begin{array}{l}\text { Dietrich Earnhart and Lubomír } \\
\text { Lízal }\end{array}$ & Aug. 2002 \\
\hline $\begin{array}{l}\text { No. 491: Does Economic Uncertainty Have an Impact on Decisions to } \\
\text { Bear Children? Evidence from Eastern Germany }\end{array}$ & $\begin{array}{l}\text { Sumon Kumar Bhaumik and } \\
\text { Jeffrey B. Nugent }\end{array}$ & July 2002 \\
\hline $\begin{array}{l}\text { No. 490: The Reallocation of Workers and Jobs in Russian Industry: } \\
\text { New Evidence on Measures and Determinants }\end{array}$ & J. David Brown and John S. Earle & Aug. 2002 \\
\hline $\begin{array}{l}\text { No. 489: The Incidence and Cost of Job Loss in a Transition Economy: } \\
\text { Displaced Workers in Estonia, 1989-1999 }\end{array}$ & $\begin{array}{l}\text { Hartmut Lehmann, Kaia Phillips } \\
\text { and Jonathan Wadsworth }\end{array}$ & Aug. 2002 \\
\hline No. 488: Integration: An Empirical Assessment of Russia & $\begin{array}{l}\text { Daniel Berkowitz and David N. } \\
\text { DeJong }\end{array}$ & Feb. 2002 \\
\hline $\begin{array}{l}\text { No. 487: Dual Inflation under the Currency Board: The challenges of } \\
\text { Bulgarian EU accession }\end{array}$ & $\begin{array}{l}\text { Nikolay Nenovsky and Kalina } \\
\text { Dimitrova }\end{array}$ & July 2002 \\
\hline $\begin{array}{l}\text { No. 486: Worker Flows, Job Flows and Firm Wage Policies: } \\
\text { An Analysis of Slovenia }\end{array}$ & $\begin{array}{l}\text { John Haltiwanger and Milan } \\
\text { Vodopivec }\end{array}$ & July 2002 \\
\hline $\begin{array}{l}\text { No. 485: Do Schumpeterian Waves of Creative Destruction Lead to } \\
\text { Higher Productivity? Panel Data Evidence from Poland }\end{array}$ & Frederic Warzynski & July 2002 \\
\hline $\begin{array}{l}\text { No. 484: Labor Market Institutions and Restructuring: Evidence from } \\
\text { Regulated and Unregulated Labor Markets in Brazil }\end{array}$ & Jasper Hoek & July 2002 \\
\hline $\begin{array}{l}\text { No. 483: The Balassa-Samuelson effect in Central and Eastern Europe: } \\
\text { Myth or reality? }\end{array}$ & $\begin{array}{l}\text { Balázs Égert, Imed Drine, Kirsten } \\
\text { Lommatzsch and Christophe } \\
\text { Rault }\end{array}$ & July 2002 \\
\hline
\end{tabular}

